\title{
Long-term Changes of Vegetation Season in Context of Spring Barley Phenology in South Moravia
}

\section{Vývoj parametrư vegetačního období v kontextu nástupu jednotlivých fenofází ječmene jarního na jï̌ní Moravě}

\author{
Hana STŘEDOVÁ ${ }^{1,2}$, Eva STEHNOVÁ ${ }^{1}$, Jana ŠKVARENINOVÁ ${ }^{3}$ \\ ${ }^{1}$ Mendel University in Brno, Faculty of AgriSciences, Zemědělská 1, CZ 61300 Brno / Mendelova univerzita v Brně, \\ Agronomická fakulta, Zemédělská 1, 61300 Brno \\ ${ }^{2}$ Czech Hydrometeorological Institute, Kroftova 43, CZ 616667 Brno / Český hydrometeorologický ústav, pobočka Brno, Kroftova \\ 43, 61667 Brno \\ ${ }^{3}$ Technical University in Zvolen, Faculty of Ecology and Environmental Sciences, T. G. Masaryka 2117/24, SK 960 53 / Technická \\ univerzita vo Zvolene, Fakulta ekológie a environmentalistiky, T. G. Masaryka 2117/24, 96053 Zvolen
}

e-mail: hana.stredova@mendelu.cz

Recenzovaný článek / Reviewed Paper

\begin{abstract}
Středová, H., Stehnová, E., Škvareninová, J., 2017: Long-term changes of vegetation season in context of spring barley phenology in South Moravia. Kvasny Prum. 63, No. 1, pp. 11-15

The paper deals with the active sum of daily average air temperature above 5,10 , and $15^{\circ} \mathrm{C}$, and with the length of the vegetation season which is given by values of the daily average values of air temperature exceeding the given threshold $\left(5,10,15^{\circ} \mathrm{C}\right)$. The average values of four long-term periods (1931-1960, 1961-1990, 2021-2050, and 2071-2100) were compared to one another. A gradual increase of all the above mentioned characteristics was found. The area of interest involves several localities in south Moravia (the Czech Republic). These findings were confronted with a long-term (1931-2012) analysis of spring barley's phenological phases and with the date of sowing and the beginning of harvest. A prolongation of the interval between sowing and harvest was found; this was probably caused by agronomy machinery advancement. A prolongation of the interval between sowing and emergence and between heading and harvest, and a shortening of the interval between emergence and heading was also proved. A trend analysis of spring barley phenophases during 1961-1990 did not prove almost any significant changes, except for a 12-day delay of the beginning of the harvest day, which was probably caused by a more effective mechanization
\end{abstract}

Středová, H., Stehnová, E., Škvareninová, J., 2017: Vývoj parametrů vegetačního období v kontextu nástupu jednotlivých fenofází ječmene jarního na jižní Moravě. Kvasny Prum. 63, č. 1, s. 11-15

Článek se zabývá sumou aktivních teplot denních průměrných teplot vzduchu nad 5,10 a $15^{\circ} \mathrm{C}$ a délkou vegetační sezóny, která je dána hodnotami denních prüměrných hodnot teploty vzduchu přesahující daný limit $\left(5,10,15^{\circ} \mathrm{C}\right)$. Prüměrné hodnoty čtyř dlouhodobých období (1931-1960, 1961-1990, 2021-2050 a 2071-2100) byly následně porovnány. Byl zjištěn postupný nárůst všech výše uvedených charakteristik. Zájmové území zahrnuje několik lokalit jižní Moravy (Česká republika). Tato zjištění byla dále konfrontována s dlouhodobými analýzami fenologických fází (1931-2012) ječmene jarního a s termíny výsevu a počátkem sklizně. Bylo zjištěno prodloužení intervalu mezi setím a sklizní. Toto je pravděpodobně způsobeno lepší zemědělskou technikou. $V$ rámci analýzy bylo zjištěno prodloužení intervalu mezi fenologickými fázemi setí a vzcházení a mezi metáním a sklizní. Dále bylo zjištěno zkrácení intervalu mezi fenologickými fázemi vzcházení a metání. Při analýze nástupů trendů fenologických fází ječmene jarního nebyly zjištěny v období 1961-1990 žádné významné změny, s výjimkou dvanáctidenního zpoždění počátku sklizně. Toto bylo pravděpodobně způsobeno účinnější zemědělskou mechanizací.

Středová, H., Stehnová, E., Škvareninová, J., 2017: Die Entwicklung von Parametern der Vegetationszeit im Kontext mit der Zusammenhang mit dem Beginn jeder phänologischen Phasen der Sommergerste in Südmähren. Kvasny Prum. 63, Nr. 1, S. 11-15

Der Artikel befasst sich mit der Summierung von durchschnittliche Aktivtagestemperaturen über die Limits $5^{\circ} \mathrm{C}, 10^{\circ} \mathrm{C}$ und $15^{\circ} \mathrm{C}$ und mit der Länge der Vegetationszeit, die durch gegebene Werte der durchschnittlichen Aktivtageslufttemperaturen über Limit $\left(5,10,15^{\circ} \mathrm{C}\right)$ gegeben wird. Die durchschnittlichen Werte von vier langzeitigen Perioden (1931-1960, 1961-1990, 2021-2050 a 2071-2100) wurden miteinander verglichen. Es wurde eine allmähliche Zunahme in allen Parametern gefunden. Das Interessengebiet erstreckt sich über mehrere Gebiete in Südmähren (Tschechische Republik). Diese Ergebnisse wurden weiter mit langfristigen Analysen der phänologischen Phasen konfrontiert (1931-2012) und mit Sommergerste Aussaatzeiten und Anfang der Ernte. Es wurde gefunden, dass Intervall zwischen Aussaat und Ernte verlängert wurde. Dies kann wahrscheinlich durch verbesserte landwirtschaftliche Technologie erklärt werden. Im Rahmen einer Analyse wurde es festgestellt das Intervall zwischen den phänologischen Phasen der Aussaat und Keimung und zwischen durch das Werfen einer Ernte zu verlängern. Es wurde ferner festgestellt, dass Intervall zwischen den phänologischen Phasen der Keimung und Earing verkürzt wurde. Bei der Analyse des Beginns eines Trends phänologischen Phasen der Sommergerste wurden im Zeitraum 1961-1990 keine wesentlichen Änderungen mit Ausnahme der zwölftägigen Verzögerung bei Beginn der Ernte gefunden. Dies kann wahrscheinlich durch eine verbesserte landwirtschaftliche Mechanisierung erklärt werden.

Keywords: phenological phases, active temperature, climate change, barley, harvest

Klíčová slova: fenologické fáze, aktivní teplota, změna klimatu, ječmen, sklizeň

\section{INTRODUCTION}

Both the plant development as well as the development of poikilothermic organisms is significantly influenced by the condition of the environment. The regime of the external temperature (of air and soil) and the surface temperature in particular impact the metabolism by changing the velocity of enzymatic reactions.
The biological temperature minimum, that is the value indicating the beginning or the ending of growth and limiting of metabolism, is important in the life of plants. Vegetation of moderate climate is generally affected by the temperature of $5{ }^{\circ} \mathrm{C}$. Temperature suitable for the period from sowing to heading varies from 9 to $16^{\circ} \mathrm{C}$. In case that temperature exceeds $20-26^{\circ} \mathrm{C}$, the growth is being retarded (Petr et al., 1987).

The onset of individual developmental phases is driven by temperature expressed as the sum of active or effective temperature. The active temperature is defined as the temperature exceeding the biological minimum which is the value of the decline of the ability to vegetate. The sum of all daily average temperature values exceeding the biological minimum (or the threshold temperature) is called 
the sum of active temperature (SAT). SAT reflects the rate of saturation of a plant's temperature demands and is also used as the criterion of crops planting regionalization. Daily average values of 0,5 , 10 , and $15{ }^{\circ} \mathrm{C}$ are considered as the temperature thresholds. The effective temperature then means also the sum of the daily/hourly average temperature exceeding the threshold when the value of the threshold is subtracted.

The on-going increase in temperature which is, according to Lobell and Field (2007), put down to the climate change, will also cause the increase in the sum of the effective temperature that would induce shortening of phenological phases, which has unfavourable impact on the yield.

For instance, Remišová and Vinceová (2006) indicated the shift of the winter rape flowering onset in Slovakia (i.e. under comparable climatic conditions) during the period 1996-2005 towards to earlier terms in reaction to March and April temperatures. An accelerated plant development, i.e. the shortening of phenophases (mainly the generative ones) is negative to a certain extent because it limits the yield.

Yield and its quality are markedly affected by the length of the vegetation season. Partial vegetation seasons are connected with given values of daily average values of air temperature. First, we can distinguish the great vegetation season determined by the beginning and the end of the season with the daily average temperature above $5{ }^{\circ} \mathrm{C}$ (VO 5), secondly, there is the main vegetation season (temperature of $10^{\circ} \mathrm{C}$ ) - VO 10 , and finally, there is the vegetation summer (temperature of $15^{\circ} \mathrm{C}$ ) - VO 15. During VO 15, intense growth and maturation occur (Sobíšek et al., 1993).

Šiška and Takáč (2008) suggest that the vegetation season could be prolonged to up to 21 days by the year 2020 and up to one month by the year 2050 because of the temperature increase.

The analysis of the data from international phenological gardens (IPG) from 1969-1998 proved 8 days acceleration of the beginning of the vegetation season in Europe.

The observed trend corresponds with the changes of the air temperature and is considered to be a consequence of the global warming. According to Chmielewski and Rötzer (2001), the increase in the average January and February temperatures (by $1{ }^{\circ} \mathrm{C}$ ) causes a 7-day earlier beginning of the vegetation season.

The climatic conditions as well as the actual weather situation influence the phenological phases onset to a certain extent (Črepinšek, 2002; Wielgolaski, 2003). Ahas (1999); Beaubien and Freeland (2000) described the marked trend of the earlier spring onset of vegetation in different parts of Europe, and even in the USA and Canada.

An assessment of phenological data from the period 1940-2008 detected an earlier onset of the phenophase beginning of flowering in case of apricot by about 13 days, i.e. 2 days per decade under the climatic conditions of the Czech Republic (Středa et al., 2009).

\section{MATERIALS AND METHODS}

\subsection{Characteristics of a vegetation season}

- Sum of active temperature exceeding $5,10,15^{\circ} \mathrm{C}$ (SAT 5, SAT 10 a SAT 15)

- Length of the great and the main vegetation season and the length of the vegetation summer (VS 5, VS 10 a VS 15)

SATs and VSs were evaluated during four long-term periods (1931-1960, 1961-1990, 2021-2050, and 2071-2100). The evaluation is based on "technical data series" (TDS) that are created in the Czech Hydrometeorological Institute (CHMI). TDS represents a fully homogenized database of daily values of climatic elements (such as mean, minimum and maximum air temperature, precipitation total, mean air humidity etc.) in a $10 \mathrm{~km}$ grid (i.e. 787 points) for the entire area of the Czech Republic from 1961 up to the present. TDS is based on the data from standard measurement on the climatologic station network and deals with the regional climatic model (RCM) ALADIN-Climate/CZ which is driven by the global climatic model ARPEGE-Climate.

Moreover, future climate conditions by up to the year 2100 can be predicted by means of the "scenario data series" (SDS) created in CHMI. SDS deals also with RCM ALADIN-Climate/CZ, and besides that, with the emissions scenario A1B (according to IPPC). The SDS network corresponds with the TDS network (i.e. 787 points in a $10 \mathrm{~km}$ grid)

The grid creation and all data processing including TDR and SDS have been implemented by the Pro ClimDB software (Štěpánek, 2007).
The reference point for the SAT and VS evaluation is the grid point situated in the town of Breclav at the altitude of 197 MASL. For a longer retrospective comparison (1931-1960), data from the publication "Agroclimatic conditions" by Kurpelová, Coufal and Čulík (1975) for the Židlochovice station in 185 MASL were employed. The distance between the Židlochovice station and the town of Břeclav is about $30 \mathrm{~km}$ (in Fig. 2 and 3 marked with *).

\subsection{Onset of phenological phases in spring barley}

The assessment of phenological phase onset deals with the phenological data observed on the CHMI station of Branišovice. The station is located about $30 \mathrm{~km}$ from the reference point in Břeclav and was chosen because of its longest available data set (i.e. 19612012). The summary of the studied phenophases and their descriptions are displayed in Table 1.

Table 1 Description of the investigated phenophases (according to Pifflová et. al, 1956)

\begin{tabular}{|l|l|}
\hline Phenophasis & Description \\
\hline Sowing (SD) & The seeds are worked into the field. \\
\hline $\begin{array}{l}\text { Emergency } \\
\text { Em) }\end{array}$ & $\begin{array}{l}\text { The first aboveground parts of plants could be } \\
\text { observed in the field. The crop is beginning to } \\
\text { create visible rows. Young plants of barley are } \\
\text { yellow-green. }\end{array}$ \\
\hline Tillering (Ti) & $\begin{array}{l}\text { More than a half of all plants have been } \\
\text { tillering already. In the axil of the lower leaf, an } \\
\text { approximately 1-cm long peak of the coiled leaf } \\
\text { has developed. The tillering begins several days } \\
\text { after the third leaf is uncoiled. }\end{array}$ \\
\hline Heading (He) & $\begin{array}{l}\text { A half of an ear is taken out from the sheath of } \\
\text { the highest leaf. }\end{array}$ \\
\hline Fully ripe (FR) & $\begin{array}{l}\text { More than a half of all plants are in the following } \\
\text { state: The grains are dry, heavy and hard to } \\
\text { break. The grain matter is rough, mealy or } \\
\text { glassy. }\end{array}$ \\
\hline Harvest (HD) & The day when the harvest begins. \\
\hline
\end{tabular}

The average value of phenophases onset and the beginning of agronomic practices of three long-term periods (1931-1960, 19601990 , and 1991-2012) have been compared. For a longer retrospective comparison (1931-1960), data from the publication "Agroclimatic conditions" by Kurpelová, Coufal and Culík (1975) for the Pohořelice station in 183 MASL were used. The distance between the Židlochovice station and the town of Břeclav is about $30 \mathrm{~km}$. Apart from that, the trend analysis of individual phenophases and practices onset during 1961-1990 was carried out.

Additionally, the average data of two long-term periods, 19311960 and 1961-1990, from other stations with similar climatic condition and altitude (Hodonín: 190 MASL, Tvrdonice: 170 MASL, Němčice nad Hanou: 204 MASL, Holešov: 220 MASL) were compared to confirm the conclusion in regard to the long-term changes of the phenophases.

Fig. 1 shows the map of all stations included into the evaluation.

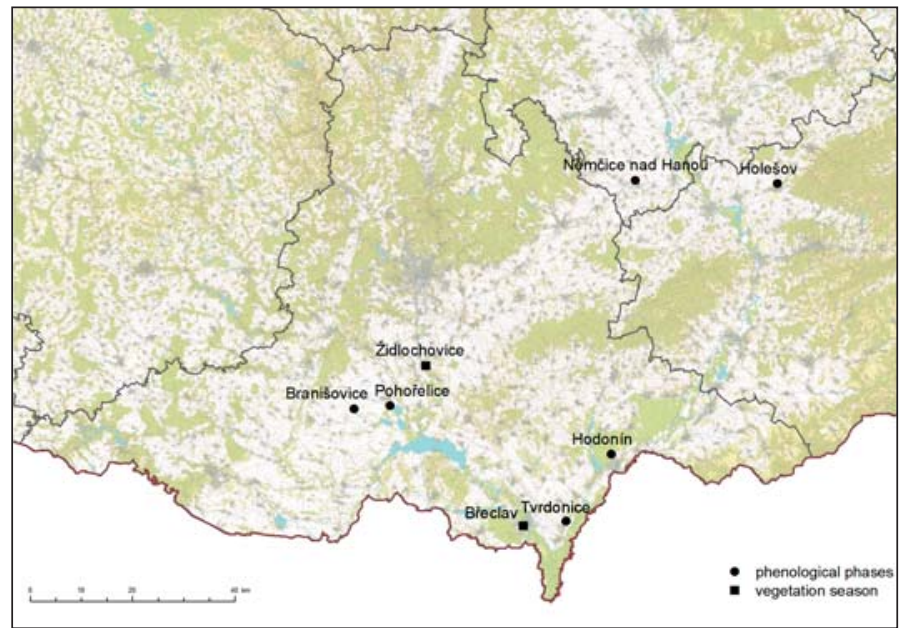

Fig. 1 Map of the area of interest with localizations of the individual stations 


\section{RESULTS AND DISCUSSION}

\subsection{Vegetation season}

The comparison of three long-term periods proved gradual increase of SAT 5, 10, 15 in all months (January to December), in all seasons (DJF-December, January, February, MAM-March, April, May, JJA-June, July, August, SON-September, October, Novem- ber) and also in the whole year (Fig. 2). The SAT 5 of 1961-1990 was by about $204^{\circ} \mathrm{C}$ higher in comparison with 1931-1961. Its further $644^{\circ} \mathrm{C}$ or $1250{ }^{\circ} \mathrm{C}$ increase has been predicted for $2021-2050$ or 2070-2100 respectively (again, compared with the period of 1931-1961).

An analogous rise was also proven in case of SAT 10 (by $193^{\circ} \mathrm{C}$ or $597^{\circ} \mathrm{C}$ or $1210^{\circ} \mathrm{C}$ higher values in 1961-1990, 2021-2050 and

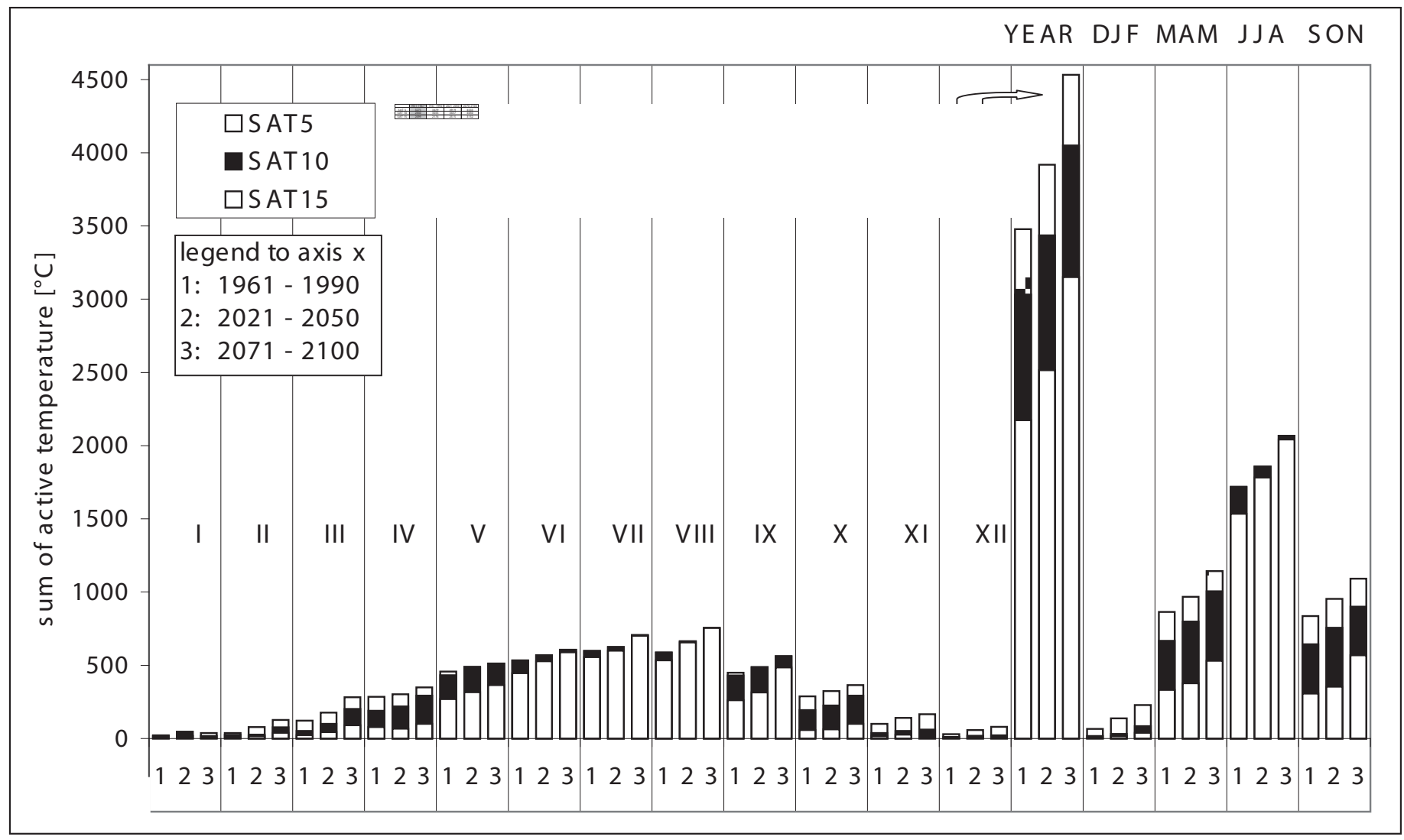

Fig. 2 Comparison of SAT 5, 10, 15 for three or four long-term periods, Břeclav locality

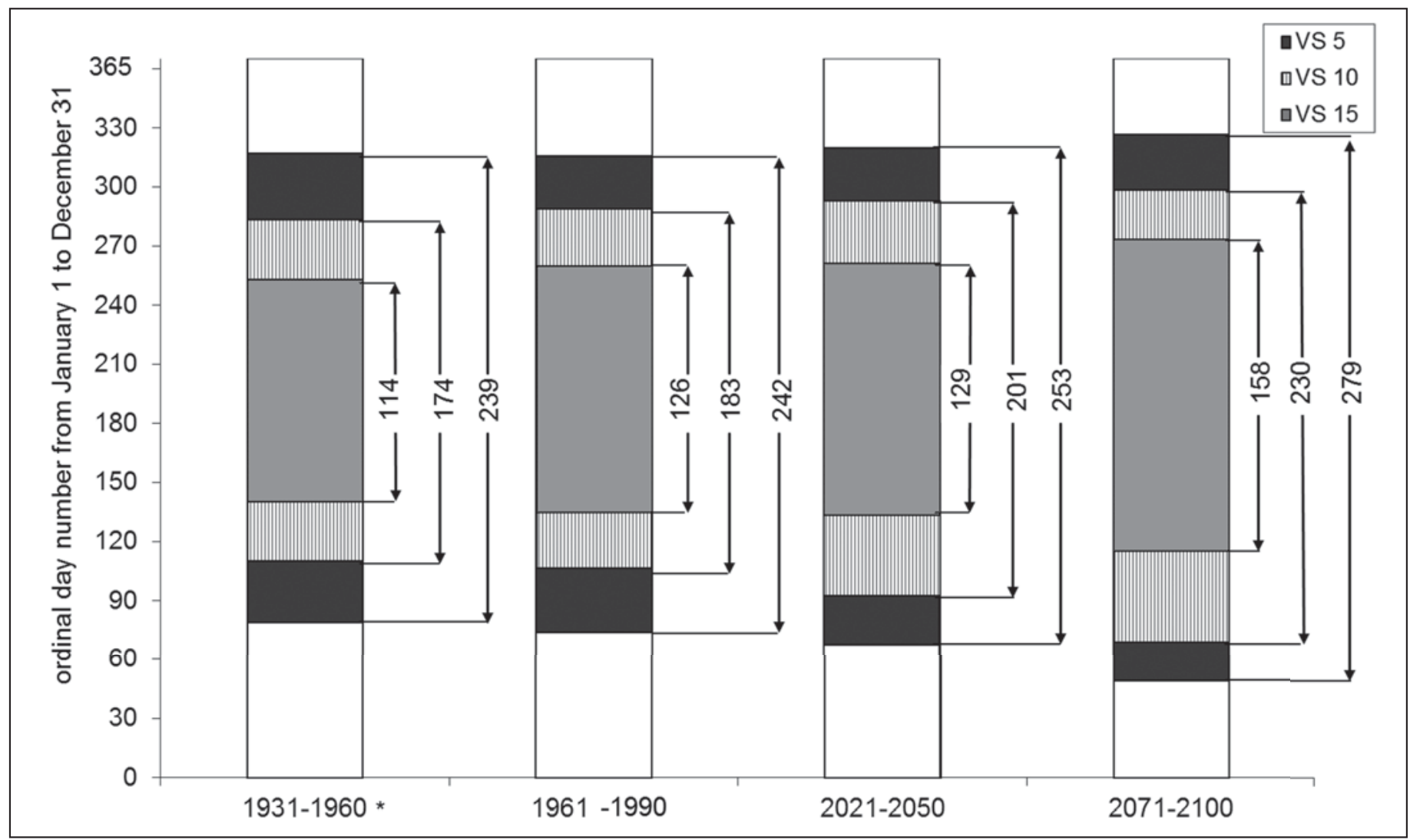

Fig. 3 Comparison of the length, the beginning and the ending of VS 5, 10, 15 for four long-term periods, Breclav locality 


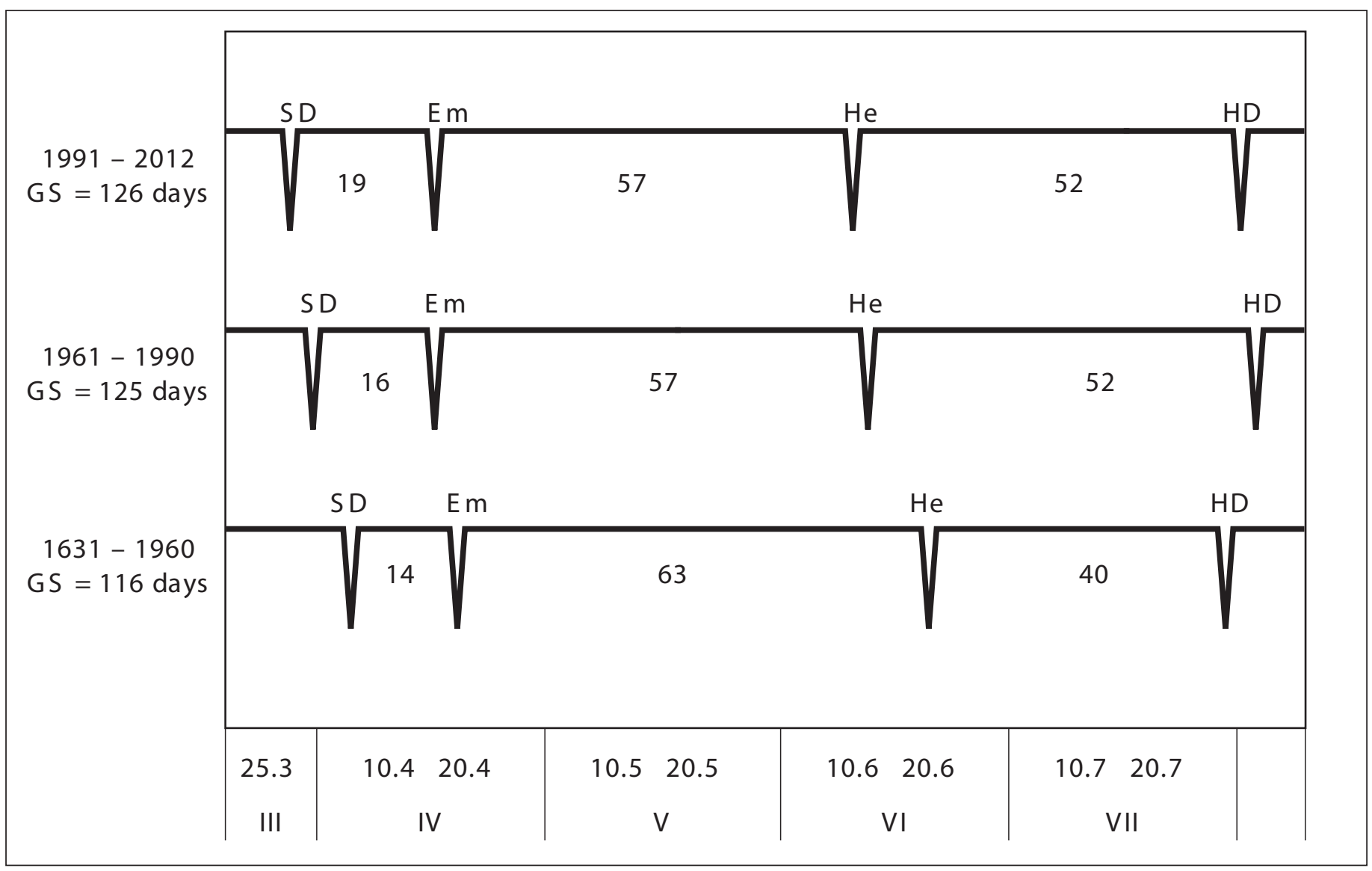

Fig. 4 Comparison of the average date of phenophases onset and the beginning of agronomic practices among three long-term periods, Branišovice locality

Table 2 Comparison of the average date of phenophases onset and the beginning of agronomic practices between two long-term periods for several stations in South Moravia

\begin{tabular}{|c|c|c|c|c|c|c|c|c|c|}
\hline locality & period & SD & $\mathrm{Em}$ & $\mathrm{He}$ & HD & SD-Em & $\mathrm{Em}-\mathrm{He}$ & He-HD & SD-HD \\
\hline \multirow{4}{*}{ Hodonín } & 1931-1961 & 82 & 94 & 161 & 197 & \multirow{2}{*}{12} & \multirow{2}{*}{67} & \multirow{2}{*}{37} & \multirow{2}{*}{116} \\
\hline & Date & 23.III & $4 . I V$ & $10 . \mathrm{VI}$ & 16.VII & & & & \\
\hline & $1961-1990$ & 79 & 98 & 158 & 200 & \multirow{2}{*}{19} & \multirow{2}{*}{$60 w w$} & \multirow{2}{*}{43} & \multirow{2}{*}{122} \\
\hline & Date & 20.3. & $8.1 \mathrm{~V}$ & 7.VI & 19.VII & & & & \\
\hline \multirow{4}{*}{ Tvrdonice } & 1931-1961 & 82 & 94 & 161 & 197 & \multirow{2}{*}{12} & \multirow{2}{*}{67} & \multirow{2}{*}{37} & \multirow{2}{*}{116} \\
\hline & Date & 23.III & $4 . I V$ & 10.VI & 16.VII & & & & \\
\hline & $1961-1990$ & 82 & 96 & 156 & 203 & \multirow{2}{*}{14} & \multirow{2}{*}{60} & \multirow{2}{*}{48} & \multirow{2}{*}{122} \\
\hline & Datum & 23.III & $6 . I V$ & $5 . \mathrm{VI}$ & 22.VII & & & & \\
\hline \multirow{4}{*}{$\begin{array}{l}\text { Němčice } \\
\text { nad Hanou }\end{array}$} & 1931-1961 & 89 & 106 & 167 & 209 & \multirow{2}{*}{17} & \multirow{2}{*}{61} & \multirow{2}{*}{43} & \multirow{2}{*}{121} \\
\hline & Date & 30.111 & 16.IV & 16.VI & 28.VII & & & & \\
\hline & 1961-1990 & 80 & 94 & 160 & 209 & \multirow{2}{*}{14} & \multirow{2}{*}{66} & \multirow{2}{*}{50} & \multirow{2}{*}{130} \\
\hline & Datum & 21.III & 4.IV & 9.VI & 28.VII & & & & \\
\hline \multirow{4}{*}{ Holešov } & $1931-1961$ & 84 & 100 & 162 & 203 & \multirow{2}{*}{16} & \multirow{2}{*}{62} & \multirow{2}{*}{42} & \multirow{2}{*}{120} \\
\hline & Date & 25.111 & $10 . \mathrm{IV}$ & $11 . \mathrm{VI}$ & 22.VII & & & & \\
\hline & $1961-1990$ & 83 & 100 & 161 & 209 & \multirow{2}{*}{17} & \multirow{2}{*}{61} & \multirow{2}{*}{49} & \multirow{2}{*}{127} \\
\hline & Date & 24.III & $10 . I V$ & 10.VI & 27.VII & & & & \\
\hline
\end{tabular}

2070-2100 respectively) and SAT $15\left(75^{\circ} \mathrm{C}\right.$ or $416^{\circ} \mathrm{C}$ or $1053^{\circ} \mathrm{C}$ higher values in 1961-1990 or 2021-2050 or 2070-2100 respectively).

Similarly, Fig. 3 presents the prolongation of all VSs in comparison with 1931-1961. VS 5 was longer by three days, VS 10 by nine days and VS 15 by twelve days. The change will probably be confirmed in the future. According to the predictions, VS 5 will be prolonged by about 14 days, VS 10 by about 27 days and VS 15 by about 15 days in 2021-2050. The values for 2071-2100 are as follows: VS 546 , VS 1056 , and VS 1544 days.

\subsection{Phenological analysis}

The evaluation of the average onset of phenophases (Em, He) and the beginning of agronomic practices (SD, HD) proved gradual prolongation of the interval between SD and HD (growing seasonGS) from 1931-1960 through 1961-1990 to 1991-2012.

In terms of phenology, the prolongation of the interval between SD and $\mathrm{Em}$ and the interval between $\mathrm{He}$ and $\mathrm{HD}$ on one hand, and shortening of the interval between $\mathrm{Em}$ and $\mathrm{He}$ on the other hand (Fig. 4) is more interesting. These conclusions are confirmed by the 


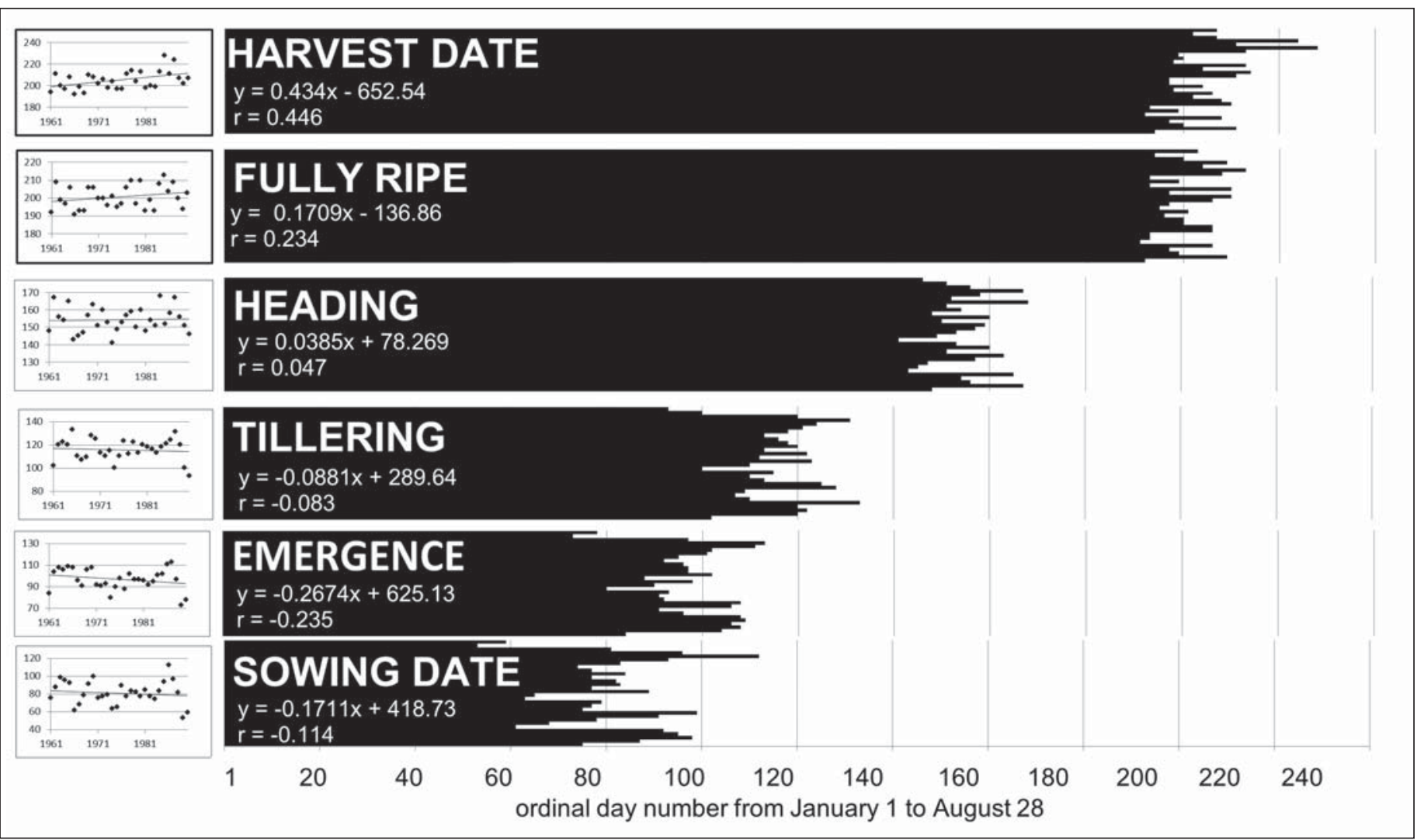

Fig. 5 A 30-year (1961-1990) trend analysis of phenophases and practices onset, Branišovice locality

comparison of two long-term periods from 1931 to 1990 for several other stations in south Moravia (Table 2).

The trend analysis of phenophases and practices onset proved a significant 12-day delay of the HD beginning in the frame of a $30-$ year period 1961-1990 (see Fig. 5). It might be explained by the climate change but rather by a more effective mechanization that has been used recently. Modern agronomy machinery allows making harvest in a much shorter time, so the harvest day can be adjusted. However, this conclusion is not confirmed by the results of the trend analysis of other stations (see Fig. 1). Apart from the significant 14day earlier onset of Em in Holešov (which could be to some extent explained by SD, thereby by agronomy machinery development again), there is no significant trend at all.

\section{CONCLUSION}

The aim of the paper was to compare the vegetation season characteristics i.e. the sum of the active temperature (SAT 5, SAT 10, and SAT 15) and the length of the vegetation season (VS 5, VS 10, and VS 15) among four long-term periods (1931-1960, 1961-1990, 2021-2050 and 2071-2100). The evaluation was based on TDS created in CHMI. The findings were subsequently confronted with the results of the phenological phases onset of spring barley based on the phenological data observed by CHMI. The research was conducted on several localities in south Moravia. The comparison of SAT and VS length proved their gradual increase and prolongation from 1931-1961 to 2071-2100. The evaluation of the average SD and HD proved gradual prolongation of the interval between them from 1931-1960 through 1961-1990 to 1991-2012. The analyses of phonological phases onset confirmed the prolongation of the interval between SD and Em and shortening of the interval between $\mathrm{He}$ and $\mathrm{HD}$ and between Em and He. A thirty-year trend analysis (19611990) of spring barley phenophases did not prove almost any significant changes, except for the 12-day delay of the HD beginning, which was probably caused by a more effective mechanization.

\section{ACKNOWLEDGEMENT}

This work was supported by project of the Ministry of Agriculture of the Czech Republic QJ1220054 "Impact of a change of climatic factors on the development of wind erosion processes, conceptual solution through the land adjustment measures".

\section{REFERENCES}

Ahas, R., 1999: Long-Term Phyto-, ornitho- and ichtyophenological Research for the $21^{\text {st }}$ Century. Int. J. Biometeorol., 42: 119-123.

Beaubien, E. G., Freeland, H. J., 2000: Spring Phenology Trends in Alberta. Canada: links to ocean temperature. Int. J. Biometeorol., 44: 53-59.

Črepinšek, Z., 2005: Spring Phenological Events in Slovenia Related to Air Temperature. Arboreta Phenologica, 48: 9-17.

Chmielewski, F. M., Rötzer, T., 2001: Response of Tree Phenology to Climate Change Across Europe. Agric. For. Meteorol., 108: 101-112.

Lobell, D. B., Field, C. B., 2007: Global scale climate-crop yield relationships and the impacts of recent warming. Environmental Research Letters 1 (2). 014002.

Petr, J. a kol., 1987: Počasí a výnosy. 1. vyd. Praha: Státní zemědělské nakladatelství, $365 \mathrm{~s}$.

Pifflová, L. et al., 1956: Příručka pro fenologické pozorovatele. Praha: Hydrometeorologický ústav, 152 pp.

Remišová, V., Vinceová, A., 2006: Vplyv teploty vzduchu na začiatok kvitnutia repky ozimej (Brassica napus L.) na Slovensku. In Fenologická odezva proměnlivosti podnebí. Brno 22. března 2006, 138-142.

Sobíšek, B. a kol., 1993: Meteorologický slovník výkladový a terminologický. 1. vyd. Praha: Academia, 594 s.

Středa, T., Rožnovský, J., Pokladníková, H., 2009: Fenologické fáze meruňky (Armeniaca vulgaris Lam.) v dlouhodobém pozorování. In: Fenológia rastlín v meniacich sa podmienkach prostredia. Zvolen: Technická univerzita vo Zvolene, s. 77-81.

Šiška, B., Takáč, J., 2008: Klimatická zmena a polnohospodárstvo Slovenskej republiky: dosledky, adaptačné opatreni a možné riešenia. 1. vyd. Bratislava: Slovenská bioklimatologická spoločnost', $66 \mathrm{~s}$.

Wielgolaski, F. E., 2003: Climatic Factors Governing Plant Phenological Phases Along a Norwegian Fjord. Int. J. Biometeorol., 47: 213-220. 